\title{
The Impact of Microeconomic Variables on Stock Return by Moderating of Money Supply
}

\author{
Borhan Sayedy $^{1}$ \& Mohd Zulkifli Ghazali ${ }^{1}$ \\ ${ }^{1}$ Azman Hashim International Business School, Universiti Teknologi Malaysia, Kuala Lumpur, Malaysia \\ Correspondence: Borhan Sayedy, Azman Hashim International Business School, Universiti Teknologi Malaysia, 54100 \\ Kuala Lumpur, Malaysia. Tel: 60-17-288-1538. E-mail: borhaniutmmu@gmail.com
}

Received: October 22, 2017

Accepted: October 31, 2017

Online Published: November 28, 2017

doi:10.5539/ass.v13n12p191

URL: https://doi.org/10.5539/ass.v13n12p191

\begin{abstract}
The purpose of this study is to empirically investigate the effect of microeconomic variables on stock return with moderating role of money supply (MS). The selected microeconomic variables in this study are debt-to-equity ratio (DE), dividend per share (DPS), and quick ratio (QR). Firm size and book-to-market value are considered as controlling variables. The period of the study is from 2003 to 2012 and the sample population of this study is 300 companies listed on Kuala Lumpur Stock Exchange (KLSE). Secondary data were collected from DataStream International, financial annual reports, and the World Bank databank. Generalized least squares (GLS) technique was used to estimate the predictive regressions in form of multiple models of panel data sets. According to the findings, MS moderates the impact of DE and QR on stock return, but does not moderate the effect of DPS on stock return. Besides, MS moderates the impact of all selected predictors on stock return. The findings of this study further show that an increase in value of a firm's debt relative to its equity would cause a decrease in the firm's stock return. The results also indicate that firms with higher QR and DPS are likely to have a higher stock return. Overall, the findings of this research are consistent with Modigliani and Miller's capital structure theory, as well as Pecking Order and Bird In Hand theory. The findings of this study would be of interest to domestic and international investors, stockbrokers, board of directors, financial managers, and policy makers.
\end{abstract}

Keywords: macroeconomic variables, microeconomic variables, money supply, stock return

\section{Introduction}

According to Chung and Ariff (2016) and Urbanovský (2016), Friedman's proposition that "money supply increases should lead to liquidity surges-to credit expansion" has yet received unanimous empirical support. Friedman (1968) stated that gradual increase in money supply is necessary for a healthy economy as it stimulates the economic expansion. Therefore, as stock market growth reflects economic expansion, money supply might be influencing stock market directly or/and through moderating the effect of microeconomic variables on stock market. Moreover, (Singh, Mehta, \& Varsha, 2011) pointed out that investors have a better chance of developing profitable investment strategies if they include macroeconomic variables in their decision making. Therefore, including the macroeconomic variables in analyzing the predictability of stock return might lead to more accurate results. Besides, Idris and Bala (2015) specified that so far, there is no consensus as to which single or combination of variables best explains stock market returns. This introduces a gap of knowledge to be filled by researchers through including other variables and/or moderators as well as control for country and economic condition.

Some characteristics in developed countries have shown a strong ability in forecasting stock returns. According to Idris and Bala (2015), the degree of explanatory power of variable(s) on stock market returns might depend on the country and period of study. The impact of macroeconomic variables on the stock market has been empirically proven for the developed countries. Nonetheless, the empirical findings for the case of developing economies is still a puzzle. Hence changes in the share prices are affected by the changes in macroeconomic performance in the well-developed markets, but results are inconclusive for the emerging markets (Rahman, Sidek, \& Tafri, 2009).

Emerging markets, as mentioned by Cohen (2002), have, on average, higher stock return than developed countries, which consist of the European Union, Japan, and the United States. Based on another study conducted by Lim (2009), there is rapid growth and low correlations between emerging markets in the South-East Asian regions, which offers lower portfolio risk and higher return for international investors. These make their stock markets interesting for both domestic and international investors seeking new opportunities to diversify their portfolio. Moreover, another study conducted by (Auzairy, Ahmad, \& Ho, 2011) stated that investors have paid more attention to ASEAN-5, especially Malaysia and Singapore, in the last three decades.

The Malaysian stock market is of special interest as it shows a different pattern of stock price movement either from the developed or other emerging economies (Rahman et al., 2009). The Malaysian stock market offers high return investment opportunities while it has yet to be studied. Therefore, this research is focusing on the stock market of 
Malaysia.

In conclusion, this study examines the impact of the 3 selected microeconomic variables on the stock return in Malaysia and investigates the moderating impact of money supply as a macroeconomic variable on this relationship. Thus, the findings of this research help in filling the gap in the literature regarding the determinants of stock return.

\section{Literature Review and Hypothesis Development}

Stock return is defined as the capital gain or loss as a result of investing in the stock market (Jones, 2000). Stock return is received through trading in the secondary market in the form of capital gain (changes in stock price) and dividends (Hällefors, 2013). Stock price is determined by demand and supply, which is usually influenced by firm characteristics and/or macroeconomic variables (Akinlesi, 2011). Therefore, this study examines the effect of both micro and macroeconomic variables on stock return.

\subsection{Microeconomic Variables}

Research on microeconomic variables and their effect on stock return in developed countries have been adequately documented. However, the impact of microeconomic variables on stock return in developing countries including Malaysia are comparatively limited and show contradicting results.

Based on the signalling theory, investors view debt as a signal of firm value and firms with high anticipated profits will take on high level of debt. Moreover, Modigliani and Miller's tradeoff theory of leverage suggests that stock price increases with leverage. The pecking order theory, however, which has been empirically observed to be the most used in determining companies' capital structure, suggests that profitable firms use less debt. Prior research on these theories have reached contradictory results. Titman and Wessels (1988), Rajan and Zingales (1995), (Hall, Hutchinson, $\&$ Michaelas, 2000) and Fama and French (2002) found that the most profitable firms more likely borrow less. These results are consistent with the pecking-order theory. However, Hovakimian et al., (2001), Korajczyk and Levy (2003), Hovakimian (2004), Hovakimian and Tehranian (2004), Frank and Goyal (2003), and Idris and Bala (2015) supported the trade-off theory and found a positive relationship between debt-to-equity ratio and stock returns. These contradictory results could be because of different economic conditions (according to Modigliani and Miller`s capital structure theory) or maybe due to the period or scope of study or lack of mediating or moderating variables. Therefore, debt-to-equity ratio is selected as one of the microeconomic variables in this study.

The dividend irrelevance theory by Modigliani and Miller essentially indicates that an issuance of dividends should have little to no effect on stock return. However, bird-in-hand theory which was developed by Myron Gordon and John Lintner contradicts the Modigliani and Miller dividend irrelevance theory. Bird-in-hand theory indicates that investors care whether their returns are from dividends or capital gains. Based on the bird-in-hand theory, shares with high dividend payouts have higher demand by investors and consequently command a higher market price. Hartono (2004) found that dividend per share negatively influence stock return. Conversely, Docking and Koch (2005), (Kothari, Lewellen, \& Warner, 2006), and Al-Shubiri (2010), found a direct relationship between dividend per share and stock return. Therefore, in order to help resolving the existing contradictory findings, this study examines the impact of dividend per share on stock return.

Quick ratio (QR) has been selected in this study as an indicator of a company's short-term liquidity. Liquidity of company describes the company's ability to meet its short-term liabilities. In the current unstable economy in Malaysia, the ability of companies to pay their debt is among the highest concerns of investors. The analysis of short-term liquidity is often important as it gives confidence to investors about a company's ability of short-term success in paying debts (Subramanyam \& Wild, 2009). QR is more conservative than current ratio because it eliminates the inventories from the current assets. Converting inventories into cash takes time and if the inventories must be sold quickly, the company must accept a lower price than their book value. Therefore, they are excluded from assets which are ready sources of immediate cash. Previous research found contradicting results on the influence of QR on stock return. Ulupui (2007), (Chang, Faff, \& Hwang, 2010), Saleem and Rehman (2011) and (Shadkam Aga, Mogaddam, \& Samadiyan, 2013) found a positive impact of QR on stock return while Stefano (2015), Hernendiastoro (2005), and Komala and Nugroho (2013) found no impact of current ratio on stock return. Therefore, this study examines the impact of QR on stock return in order to add to the body of literatures and help resolving the contradictory findings.

The following hypotheses were developed based on the above discussion.

H1: Microeconomic variables have a significant impact on stock return

H1a: D/E has a significant negative impact on stock return

H1b: DPS has a significant positive impact on stock return

H1c: Quick ratio has a significant positive impact on stock return

\subsection{Money Supply}

Monetary Portfolio Theory suggests that changes in money supply alter the equilibrium position of money, thereby altering the composition and price of assets in an investor's portfolio (Rozeff, Rozeff, \& Kinney, 1976). In addition, changes in money supply may impact on real economic variables, thereby having a lagged influence on stock returns (Rogalski \& Vinso, 1977). Both of these mechanisms suggest a positive relationship between changes in money supply 
and stock returns (Bilson, Brailsford, \& Hooper, 2001). According to a conventional economic theory by Fama (1981), an increase in money supply leads to an increase in discount rates, which in turn lowers the price of stock, and thus, confers a negative effect. However, Mukherjee and Naka (1995) argued that if an increase in money supply leads to economic expansion via increased cash flows, stock prices would benefit from economic growth led by such an expansionary monetary policy. Maysami and Koh (2000) showed that money supply is positively related to stock market in the cases of Singapore and Japan. Their findings support the view of Mukherjee and Naka (1995) regarding long run and short run dynamic interaction between money supply and stock returns (Rahman et al., 2009). (Brunie, Hamburger, \& Kochin, 1972), (Blume, Kraft, J., \& Kraft, A., 1977), and Hasan and Javed (2009) found a strong linkage between money supply and stock return. However, Cooper (1974) and Hashemzadeh and Taylor (1988) found that there is no significant link between the two variables. In the Malaysian context, Ibrahim and Aziz (2003) studied causal relations and dynamic linkages between the Malaysian stock market and four macroeconomic variables, including exchange rate, money supply, industrial product, and CPI. They found dynamic responses of the stock prices to changes in macroeconomic variables. Lagged responses of stock price in their study to real economic activity means inefficiency in the Malaysian equity market. Although based on their findings, the role of money supply in the dynamic behavior of equity prices seemed to decline over time, periodically, its relationship to equity prices was uncertain and, in the long run, was negative. This means that shocks in money supply may feed into the economy's inflation instability, expectations of contractions, and risk elements. Accordingly, this results in adverse or uncertain behavior of the stock market.(Rahman et al, 2009)

According to the above studies, since money supply affects discount rate and liquidity, it might influence the impact of $\mathrm{D} / \mathrm{E}, \mathrm{DPS}$, and QR on firm performance and stock return. This is because the influence of the selected microeconomic variables on stock return depends on discount rate and liquidity. Therefore, this study examines the moderating impact of money supply on the relationship between the three selected microeconomic variables and stock return. Accordingly, the following hypotheses were developed.

$\mathrm{H} 2$ : Money supply moderates the impact of microeconomic variables on stock return

H2a: Money supply moderates the impact of D/E on stock return

$\mathrm{H} 2 \mathrm{~b}$ : Money supply moderates the impact of DPS on stock return

H2c: Money supply moderates the impact of Quick ratio on stock return

\section{Research Method}

\subsection{Sample and Data Selection}

All firms listed in the Kuala Lumpur Stock Exchange (KLSE or Bursa Malaysia) were the subjects of this research. According to the Bursa Malaysia annual reports, the total number of listed companies in 2003 was 906(the base year of study period). The sample population of this study is 300 companies listed in KLSE. The sampling method used in this study is convenient random sampling, as the 300 companies were selected randomly out of 342 with available data from Datastream International. The study examines a sample period of 2003 to 2012 and studies the effect of experimental variables and the moderator on stock return of subsequent years because stock return might lag behind the economic activities (Kwon \& Shin, 1999). This study has used secondary data collected from three main sources of DataStream International, financial annual reports, and the World Bank databank. The two sources used to collect data pertaining to microeconomic variables and stock return were DataStream and financial annual reports. The source used for macroeconomic data was the World Bank databank.

\subsection{Variables Measurement}

\subsubsection{Debt to Equity (D/E)}

The debt-to-equity ratio (D/E) is a financial ratio indicating the relative proportion of shareholders' equity and debt used to finance a company's assets (Peterson \& Fabozzi, 1999).

$\mathrm{D} / \mathrm{E}$ is defined as a measure of a company's financial leverage. $\mathrm{D} / \mathrm{E}$ is also known as gearing, leverage or risk ratio. $\mathrm{D} / \mathrm{E}$ is calculated as follow:

$$
D / E=\text { Total Liabilities / Average shareholders' equity }
$$

Total liabilities is the sum of both short term and long-term liabilities, while average shareholders' equity is the mean value of stockholders' equity of two consecutive fiscal years. Changes in D/E ratio can potentially affect stock return of companies because of changes in cost of debt and risk of bankruptcy. High amount of D/E ratio of a company shows that the firm has been aggressive in financing its growth by using debt rather than equity or internal financing. This might result in lower stock return because of higher cost of debt. Conversely, a smaller amount of debt to equity ratio may benefit shareholders as earnings would be spread among them rather than being paid as interest. Besides, the cost of debt will be lower as well as bankruptcy cost which results in higher demand for the stock and potentially higher return.

\subsubsection{Dividend per Share (DPS)}

The dividend yield or dividend-price ratio of a share is the dividend per share divided by the price per share (Cohen, 2002). 
DPS is calculated as follow:

$$
D P S=(D-S D) / S
$$

Where $\mathrm{D}$ is the sum of dividends over a period (1 year), SD is the special (one-time) dividends, and $\mathrm{S}$ is the shares outstanding for the period. Based on bird-in-hand theory, DPS can influence stock return as the demand for shares with high DPS is potentially higher than the other shares. Bird-in-hand theory indicates that investors are indifferent to whether their returns from holding a stock arise from dividends or capital gains. According to this theory, shares with high dividend payouts have higher demand by investors and consequently command a higher market price.

\subsubsection{Quick Ratio (QR)}

Quick ratio measures the ability of a company to use its near cash or quick assets to immediately extinguish or retire its current liabilities. Quick assets include those current assets that can be quickly converted to cash at a price close to their book values. Unlike current ratio, inventory is excluded from the sum of assets in the quick ratio (Tracy \& Tracy, 2004). In other words, quick ratio is a measure of how well a company can meet its short-term financial liabilities. QR also known as the acid-test ratio, is calculated as follow:

$$
Q R=(\text { Cash }+ \text { Marketable Securities }+ \text { Accounts Receivable }) /(\text { Current Liabilities })
$$

Quick ratio is a more conservative version of current ratio. Although the two are similar, the quick ratio provides a more rigorous assessment of a company's ability to pay its current liabilities. It does this by eliminating all but the most liquid of current assets from consideration. Inventory is the most notable exclusion, and it is not included in quick ratio because it is not as rapidly convertible to cash and is often sold on credit.

\subsubsection{Money Supply}

Money supply (or money stock) is the total amount of monetary assets available in an economy at a specific time. There are several ways to define money but standard measures usually include currency in circulation and demand deposits (DeFusco, Johnson, \& Zorn, 1990). Money supply includes safe assets, such as cash, coins, and balances held in checking and savings accounts that businesses and individuals can use to make payments or hold as short-term investments.

The different types of money in the money supply are classified as M0, M1, M2, and M3 based to the type and the size of the account in which the instrument is kept. M0 and M1are called narrow money as well, and include notes and coins that are in circulation and other money equivalents that can be converted easily to cash. M2 includes M1, short-term deposits in banks and certain money market funds. M3 includes M2 in addition to long-term deposits but it is no longer included in the reporting by the Federal Reserve. M0 (MZM), or money zero maturity, is a measure that includes financial assets with zero maturity and that are immediately redeemable at par. In this research similar to related studies such as Vejzagic and Zarafat (2013), broad money (M2) is selected as representative of money supply.

\subsubsection{Stock Return}

Stock return is defined as the capital gain or loss as a result of investing in the stock market (Jones, 2000). Stock return is received through trading in the secondary market in the form of capital gains (changes in stock price) and dividends (Hällefors, 2013).

Stock return is the dependent variable in this research and it's measured by calculating return index (RI), which shows the growth in value of a share over a specified period of time. According to DataStream International, RI is calculated as follow:

$$
R I_{t}=R I_{t-1} * \frac{P I_{t}}{P I_{t-1}} *\left(1+\frac{D Y_{t}}{100} * \frac{1}{N}\right)
$$

Where: $R I_{t}$ is return index on day $\mathrm{t} ; R I_{t-1}$ is return index on previous day; $P I_{t}$ is price index on day $\mathrm{t} ; P I_{t-1}$ is price index on previous day; $D Y_{t}$ is dividend yield \% on day $\mathrm{t} ; \mathrm{N}$ is number of working days in the year (taken to be 260).

\subsubsection{Total Assets}

In financial accounting, an asset is an economic resource. Anything tangible or intangible that can be owned or controlled to produce value and that is held by a company to produce positive economic value is an asset. Simply stated, assets represent value of ownership that can be converted into cash (although cash itself is also considered an asset) (Sullivan, 2003).

Total assets is the sum of all current and non-current assets and equals to the sum of total liabilities and stockholders' equity. Total assets is calculated as follow:

$$
\text { Total Assets }=\text { liabilities }+ \text { stockholders'equity }
$$

As similar studies by Fama and French (1993) and (Kouser et al., 2011) this research is considering total assets as a proxy of firm size.

\subsubsection{Book to Market Ratio}

The book-to-market ratio is a ratio used to find the value of a company by comparing book value of a firm to its 
market value. The book value is calculated by looking at the firm's historical cost, or accounting value, while market value is determined in the stock market through its market capitalization. Book to market ratio is calculated as follow:

$$
\text { Book to Market Ratio = (Book value of firm }) /(\text { Market value of firm })
$$

The book-to-market ratio attempts to identify undervalued or overvalued securities. In basic terms, if the ratio is above 1 , the stock is undervalued and if it is less than 1, the stock is overvalued. This financial ratio has been considered in this current study, as it is one of the main common risk factors in the returns on stocks (Fama \& French, 1993).

\subsection{Regression Models}

As similar studies (Frazier, Tix, \& Barron, 2004) three steps of applying a hierarchical multiple regression were employed to investigate the moderating impact of money supply.

Step 1: the impact of predictor variables on dependent variable (Model 1):

$$
S R_{i, t+1}=\alpha_{0}+\beta_{1} D E_{\mathrm{i}, t}+\beta_{2} D P S_{\mathrm{i}, t}+\beta_{3} Q R_{\mathrm{i}, t}+\varepsilon_{i, t}
$$

Where $S R_{i, t+1}$ is logarithm of stock return index of company i in year $\mathrm{t}+1 ; D E_{i, t}$ is debt to equity ratio of company $\mathrm{i}$ in year $\mathrm{t} ; D P S_{i, t}$ is Dividend per shar of company $\mathrm{i}$ in year $\mathrm{t} ; Q R_{i, t}$ is quick ratio of company $\mathrm{i}$ in year $\mathrm{t}$; $\alpha_{0}$ is constant. The disturbance term denoted as $\varepsilon_{i, t}$ was assumed to be serially uncorrelated with mean zero.

Step 2: the impact of moderator variable on dependent variable (Model 2):

$$
S R_{i, t+1}=\alpha_{0}+\beta_{1} D E_{\mathrm{i}, t}+\beta_{2} D P S_{\mathrm{i}, t}+\beta_{3} Q R_{\mathrm{i}, t}+\beta_{4} M S_{t}+\varepsilon_{i, t}
$$

Where $M S_{t}$ is natural logarithm of money supply in year $\mathrm{t}$

Step 3: the effect of interactions among the predictor variables and the moderator on dependent variable (Model 3):

$$
S R_{i, t+1}=\alpha_{0}+\beta_{1} D E_{\mathrm{i}, t}+\beta_{2} D P S_{\mathrm{i}, t}+\beta_{3} Q R_{\mathrm{i}, t}+\beta_{4} M S_{t}+\beta_{5} M S_{t} D E_{\mathrm{i}, t}+\beta_{6} M S_{t} D P S_{\mathrm{i}, t}+\beta_{7} M S_{t} Q R_{\mathrm{i}, t}+\varepsilon_{i, t} \text { (9) }
$$

Where: $M S_{t} D E_{i, t}$ is interaction of natural logarithm of money supply in year $\mathrm{t}$ and debt to equity ratio of company $\mathrm{i}$ in year $\mathrm{t} ; M S_{t} D P S_{i, t}$ is interaction of natural logarithm of money supply in year $\mathrm{t}$ and dividend per share of company $\mathrm{i}$ in year $\mathrm{t} ; M S_{t} Q R_{i, t}$ is interaction of natural logarithm of money supply in year $\mathrm{t}$ and quick ratio of company $\mathrm{i}$ in year $\mathrm{t}$. The disturbance term denoted as $\varepsilon_{i, t}$ was assumed to be serially uncorrelated with mean zero.

\section{Results and Analyses}

Statistical software STATA 13.0 was employed to analyze the data. In addition, according to Basiruddin (2011), Ordinary Least Square (OLS) regression may not be an efficient estimator as some of the assumptions are not fulfilled. Therefore, this study as similar research such as (Kheradyar, Ibrahim, \& Nor, 2011) applied generalized least squares (GLS) method to tackle the heteroskedasticity and non-normality distributed residuals.

\subsection{Descriptive Statistics}

An overview of the nature of the data is presented in table 1. This table presents the descriptive statistics details including the number of observations, minimum, maximum, mean and standard deviation for all the variables in this study. Moreover, the original value of stock return, total assets, money supply and interest rate are presented as well as their $\log$ forms.

Table 1. Descriptive Statistics

\begin{tabular}{cccccc}
\hline Variables & $\mathrm{N}$ & Minimum & Maximum & Mean & Std. Deviation \\
\hline SR & 2991 & 0.0334238 & 4.030512 & 1.942313 & 0.7253347 \\
DE & 3000 & 0 & 8.9437 & 0.6019867 & 0.893689 \\
DPS & 3000 & 0 & 0.9308903 & 0.0174546 & 0.0584713 \\
QR & 2733 & 0.01 & 27.59 & 1.882752 & 2.707478 \\
BM & 2990 & 0.05 & 20.43987 & 1.089716 & 1.45524 \\
TA & 3000 & 6.108458 & 10.78682 & 8.066754 & 0.7103446 \\
MS & 3000 & 25.70557 & 26.78745 & 26.246 & 0.3497253 \\
OSR & 2991 & 0.08 & 10726.84 & 412.4103 & 1142.694 \\
OTA & 3000 & 1283684 & $6.12 \mathrm{E}+10$ & $9.28 \mathrm{E}+08$ & $3.96 \mathrm{E}+09$ \\
OMS & 3000 & $1.46 \mathrm{E}+11$ & $4.30 \mathrm{E}+11$ & $2.66 \mathrm{E}+11$ & $9.23 \mathrm{E}+10$ \\
MSDE & 3000 & 0 & 235.7855 & 15.78395 & 23.37906 \\
MSDPS & 3000 & 0 & 24.40195 & 0.4596342 & 1.538127 \\
MSQR & 2733 & 0.2678745 & 720.509 & 49.40938 & 70.94367 \\
\hline
\end{tabular}

Note. SR = Log of Stock Return Index; DE = Debt to Equity Ratio; DPS = Dividend per Share; QR = Quick Ratio; BM = Book to Market Value; TA $=$ Log of Total Assets; INT = Natural Log of Interest Rate; MS $=$ Natural Log of Broad Money; OSR = Original Value of Stock Return Index; OTA = Original Value of Total Assets; OMS = Original Value of Broad Money; OINT = Original Value of Interest rate; INTDE = Interaction of INT and DE; INTDPS = Interaction of Interest rate and DPS; INTQR = Interaction of Interest rate and QR; MSDE = Interaction of Broad Money and DE; MSDPS = Interaction of Broad Money and DPS; MSQR = Interaction of Money Supply and QR. 


\subsection{Empirical Results of Multiple Regressions}

Table 2 presents the results of hierarchical multiple regressions related to Models 1, 2 and 3. Model 1 includes the selected microeconomic variables (DE, DPS, and QR) as independent variables (first step). Model 2 includes the moderator variables (second step). Model 3 includes the interaction terms (MSDE, MSDPS, and MSQR).

Table 2. The result of the Generalized Least Square (GLS) regression to examine the effect of DE, DPS, QR, and MS as moderator on stock return

\begin{tabular}{cccc}
\hline Variables & Model 1 (Coefficient) & Model 2 (Coefficient) & Model 3 (Coefficient) \\
\hline DE & $-0.0933632^{*}$ & $-0.09466^{*}$ & $1.614912^{*}$ \\
DPS & $1.613494^{*}$ & $1.644628^{*}$ & 8.32916 \\
QR & $0.0135595^{*}$ & $0.013583^{*}$ & $-0.21349^{* *}$ \\
BM & $0.1300604^{*}$ & $0.129793^{*}$ & $0.130493^{*}$ \\
TA & $0.5130087^{*}$ & $0.528224^{*}$ & $0.529442^{*}$ \\
MS & & -0.01309 & 0.010849 \\
MSDE & & & $-0.06546^{*}$ \\
MSDPS & & & -0.25518 \\
MSQR & & & $0.00868^{* *}$ \\
cons & -2.327459 & -2.10515 & -2.74079 \\
$\mathrm{R}^{2}$ & 0.3753 & 0.3754 & 0.3841 \\
Change in R & - & 0.0001 & 0.0087 \\
Sig. F & 0.000 & 0.0000 & 0.0000 \\
\hline
\end{tabular}

Note. ${ }^{*}$ significant at 1 percent level; ${ }^{* *}$ significant at 5 percent level.

According to the results the $\mathrm{F}$ statistic in Model 1 is significant (Sig. $\mathrm{F}=0.000$ ) and shows $\mathrm{R}^{2}$ of 0.3753 , indicating that the selected microeconomic variables (DE, DPS, and QR) can explain $37.53 \%$ of the variations in stock return. Model 1 reveals that DE significantly and negatively ( $p$-value $<0.01$, Coefficient $=-0.0933632$ ) affects stock return, but DPS and QR significantly and positively ( $\mathrm{p}$-value $<0.01$, Coefficient $=1.613494$ and 0.0135595 ) affect stock return. Therefore, it can reasonably be concluded that hypotheses H1, H1a, H1b, and H1c are accepted.

Model 2 shows that the F statistic is significant (Sig. $\mathrm{F}=0.000$ ), but the impact of money supply on stock return is not significant ( $\mathrm{p}$-value $>0.1$ ).

Model 3 which presents the impact of interaction terms (MSDE, MSDPS, and MSQR) on stock return is significant and has stronger explanatory power of 0.384 . Model 3 shows 0.009 change in $\mathrm{R}^{2}$ compared to model 2 , which means that hypothesis $\mathrm{H} 2$ is accepted. Regarding the interaction terms (MSDE, MSDPS, and MSQR), the impact of MSDE is significant at $1 \%$ level and negative ( $\mathrm{p}$-value $<0.01$, Coefficient $=-0.06546$ ), and the impact of MSQR is significant and positive at $5 \%$ level ( $\mathrm{p}$-value $<0.05$, Coefficient $=0.00868$ ), but the impact of MSDPS is not significant ( $\mathrm{p}$-value $>$ 0.1 ). Therefore, based on the results of model 3 hypotheses $\mathrm{H} 2, \mathrm{H} 2 \mathrm{a}$ and $\mathrm{H} 2 \mathrm{c}$ are accepted, but hypothesis $\mathrm{H} 2 \mathrm{~b}$ is rejected.

\section{Discussion of Results}

The first set of the findings in this study, which were based on the relationship between microeconomic variables (DE, DPS, and QR) and stock return in Malaysia, demonstrated that microeconomic variables could significantly influence stock return. Results pertaining to the effect of debt-to-equity on stock return showed significant negative influence, which is consistent with the pecking-order theory. However, according to the findings dividend per share positively affects stock return in Malaysia, which is consistent with the bird-in-hand theory. According to the results, quick ratio has a significant and positive impact on stock return which is consistent with the findings of Ulupui (2007), Chang et al (2010), Saleem \& Rehman (2011) and Aga et al(2013). Relationships between microeconomic variables and stock return have been investigated in a considerable number of studies but they have presented various results. Studies on the impact of microeconomic variables on stock return in developing countries are limited compared to developed countries and they show contradicting results. Al-Shubiri (2010) studied the impact of microeconomic and macroeconomic variables on the Amman Stock Exchange for the period of 2005 -2008. Based on the findings of his study, dividend payout percentage was the only effective variable on stock price of the Amman Stock Exchange. However, Idris \& Bala (2015) studied the effect of firms' specific characteristics on stock return in Nigeria and found debt-to-equity ratio as the only influential variable. Sari and Hutagaol (2009) conducted a study in Indonesia on the influence of capital structure, business risk, and the market risk. The results of their research showed that the capital structure, which is measured by debt to equity ratio, and stock return are highly and positively related. However, in another study carried out by (Ahmad, Abdullah, \&Roslan, 2012) on the effect of capital structure on firm performance, there was no significant impact of short term, long term or total debt on firm performance. These conflicting results could be because of different methodologies, scopes, or lack of moderating or mediating variables (Hsu \& Fang, 2009); (Kamukama, Ahiauzu, \& Ntayi, 2011); (Ye, Chen, \& Jin, 2006); (Dadashinasab \& Sofian, 2014).

The second set of the findings in this study were related to the moderation effect of money supply on the relationship 
between the selected microeconomic variables and stock return in Malaysia. Based on the results money supply is not individually value relevant to stock return, but it is value relevant through moderating the effect of microeconomic variables. According to the findings, debt-to-equity ratio and quick ratio are value relevant to stock return in the Malaysian context, both directly and through the moderation of money supply. Nevertheless, dividend per share is individually value relevant to stock return, but it is not value relevant through the moderation of money supply. Therefore, findings suggest that a higher amount of debt compared to equity results in a higher stock return in terms of raising money supply. Since a larger money supply leads to higher investment, demands for stocks would be higher. Meanwhile, in such an economic condition, money in circulation is increased which leads to more purchasing power for investors. In the meantime, companies could have a higher debt with lower risk in this condition, leading to a higher stock return. Moreover, findings suggest that quick ratio could positively affect stock return and could be value relevant to stock return through moderation of money supply. Firms with higher quick ratio are considered easier to liquidate and, also, money supply leads to more liquidity based on liquidity effect. Therefore, companies with a higher quick ratio could have a much higher stock return in the presence of a higher money supply. Modigliani and Miller's capital structure theory Ross et al. (2002) along with related studies by Urbanovský (2016), Rahman et al. (2009), Sieng and Leng (2005), R. Cooper et al (2004), and Omran (2003) support the findings.

\section{Conclusion}

This study examined the impact of 3 selected microeconomic variables (DE, DPS, QR) on stock return in Malaysia as well as testing the moderating effect of money supply on their relationships. The period of the study was from 2003 to 2012 and the sample population of this study was 300 companies listed on Kuala Lumpur Stock Exchange (KLSE). This study applied generalized least squares (GLS) method to tackle the heteroscedasticity and non-normality distributed residuals.

The results seem to suggest that the microeconomic variables have a strong explanatory power in stock return predictability. Based on the findings debt-to-equity ratio (DE) negatively, and dividend per share (DPS), and quick ratio $(\mathrm{QR})$ positively affect the stock return in Malaysia. The negative impact of DE on stock return could be due to lower cost of debt. This means that companies with less amount of debt compare to equity have lower cost of debt and lower risk of bankruptcy, consequently they will have more demand for their stocks thus higher stock return. The positive impact of DPS on stock return is because most investors prefer the assurance of return through dividends rather than uncertainty of capital gain through changes in stock price. The positive influence of QR on stock return could be because higher QR gives the investors an assurance about the firm's ability to payout its debt. Therefore, stocks of companies with higher QR have more demand thus more increase in price and higher return on their stock.

This study also found that the impact of microeconomic variables on stock return could be moderated by money supply as a macroeconomic variable. The moderating impact of macroeconomic variables has been overlooked in previous research. According to the results of this research, the influence of microeconomic variables on stock return is increased by introducing money supply as a moderator. The findings suggest that higher amount of debt-to-equity ratio decreases the stock return in the subsequent year. However, in term of increasing money supply by policy makers, higher debt-to-equity ratio causes higher stock return in the following year. This could be as a result of lower cost of debt for the companies and consequently having lower bankruptcy risk, while money supply is high. Moreover, the results pertaining the impact of quick ratio on stock return suggest that higher quick ratio leads to higher stock return in subsequent year. However, based on the findings, increasing money supply decreases the positive effect of quick ratio on stock return. This might be due to taking advantage of lower cost of debt while money supply is high.

\section{References}

Ahmad, Z., Abdullah, M. N. H., \& Roslan, S. (2012). Capital Structure Effect on Firms Performance : Focusing on Consumers and Industrials Sectors on Malaysian Firms. International Review of Business Research Papers, 8(5), $137-155$.

Akinlesi, O. A. (2011). Share Price Determination and Corporate Firm Characteristics. Covenant University.

Al-Shubiri, F. (2010). Analysis the Determinants of Market Stock Price Movements: An Empirical Study of Jordanian Commercial Banks. International Journal of Business and Management, 5(10), 137. Retrieved from http://www.ezproxy.dsu.edu:2048/login?url=http://proquest.umi.com/pqdweb?did=2223174981\&Fmt=7\&clientId $=18865 \&$ RQT $=309 \&$ VName $=$ PQD

Angela, L., Komala, P., \& Nugroho, P. I. (2013). The Effects of Profitability Ratio , Liquidity , and Debt towards Investment Return. Journal of Business and Economics, 4(11), 1176-1186.

Auzairy, N. A., Ahmad, R., \& Ho, C. S. F. (2011). Stock Market Deregulation, Macroeconomic Variables and Stock Market Performances. International Journal of Trade, Economics and Finance, 2(6), $495-500$. https://doi.org/doi:10.7763/ijtef.2011.v2.155

Basiruddin, R. (2011). Durham E-Theses The Relationship Between Governance Practices , Audit Quality and Earnings Management: UK Evidence PRACTICES, AUDIT QUALITY AND EARNINGS MANAGEMENT : UK EVIDENCE A thesis submitted to Durham University in fulfilment of the.

Bilson, C. M., Brailsford, T. J., \& Hooper, V. J. (2001). Selecting macroeconomic variables as explanatory factors of 
emerging stock market returns. Pacific-Basin Finance Journal, 9(4), 401-426. https://doi.org/10.1016/S0927-538X(01)00020-8

Blume, M. R., Kraft, J., \& Kraft, A. (1977). Determinants of common stock prices: a time series analysis. The Journal of Finance, 32(2), 417-425. https://doi.org/doi:10.2307/2326775

Britten - Jones, M., \& Neuberger, A. (2000). Option prices, implied price processes, and stochastic volatility. The Journal of Finance, 55(2), 839-866. https://doi.org/https://doi.org/10.1111/0022-1082.00228

Brunie, C. H., Hamburger, M. J., \& Kochin, L. A. (1972). Money and stock prices: the channels of influence. The Journal of Finance, 27(2), 231-249.

Chang, Y. Y., Faff, R., \& Hwang, C.-Y. (2010). Liquidity and stock returns in Japan: New evidence. Pacific-Basin Finance Journal, 18(1), 90-115. https://doi.org/http://dx.doi.org/10.1016/j.pacfin.2009.09.001

Chung, T., \& Ariff, M. (2016). A test of the linkage among money supply, liquidity and share prices in Asia. Japan and the World Economy, 39, 48-61. https://doi.org/http://dx.doi.org/10.1016/j.japwor.2016.07.001

Cohen, R. (2002). The relationship between the equity risk premium, duration and dividend yield. Wilmott Magazine, 44(April), 84-97. https://doi.org/10.1002/wilm.42820020122

Cooper, R., Lee, M., Howe, C., \& Hamzah, M. A. (2004). Relationship between Macroeconomic Variables and Stock Market Indices: Cointegration Evidence from Stock Exchange of Singapore's All-S Sector Indices. Jurnal Pengurusan, 24, 47-77.

Cooper, R. V. L. (1974). Efficient capital markets and the quantity theory of money. The Journal of Finance, 29(3), 887-908. https://doi.org/https://doi.org/10.2307/2978598

Dadashinasab, M., \& Sofian, S. (2014). The impact of intellectual capital on firm financial performance by moderating of dynamic capability. Asian Social Science, 10(17), 93-100. https://doi.org/10.5539/ass.v10n17p93

DeFusco, R. A., Johnson, R. R., \& Zorn, T. S. (1990). The effect of executive stock option plans on stockholders and bondholders. The Journal of Finance, 45(2), 617-627. https://doi.org/https://doi.org/10.2307/2328674

Docking, D. S., \& Koch, P. D. (2005). Sensitivity of investor reaction to market direction and volatility: dividend change announcements. Journal of Financial Research, 28(1), 21-40. https://doi.org/https://doi.org/10.1111/j.1475-6803.2005.00112.x

Fama, E. F. (1981). Stock returns, real activity, inflation, and money. The American Economic Review, 71(4), $545-565$.

Fama, E. F., \& French, K. R. (1993). Common risk factors in the returns on stocks and bonds. Journal of Financial Economics, 33(1), 3-56. https://doi.org/10.1016/0304-405X(93)90023-5

Fama, E. F., \& French, K. R. (2002). Testing Trade-Off and Pecking Order Predictions About Dividends and Debt. The Review of Financial Studies, 15(1), 1-33. Retrieved from http://dx.doi.org/10.1093/rfs/15.1.1

Frank, M. Z., \& Goyal, V. K. (2003). The effect of market conditions on capital structure adjustment. Finance Research Letters, 1(1), 47-55. https://doi.org/10.1016/S1544-6123(03)00005-9

Frazier, P. A., Tix, A. P., \& Barron, K. E. (2004). Testing moderator and mediator effects in counseling psychology $\begin{array}{lllll}\text { research. Journal of } & \text { Counseling }\end{array}$ https://doi.org/https://doi.org/10.1037/0022-0167.51.1.115

Friedman, M. (1968). The role of monetary policy. The American Economic Review, 58(1), 1-17.

Hall, G., Hutchinson, P., \& Michaelas, N. (2000). Industry Effects on the Determinants of Unquoted SMEs' Capital Structure. International Journal of the Economics of Business, 7(3), $297-312$. https://doi.org/10.1080/13571510050197203

Hällefors, H. (2013). On the Relationship Between Accounting Earnings and Stock Returns Model Development and Empirical Tests Based on Swedish Data. Stockholm School of Economics,

Hartono, J. (2004). THE RECENCY EFFECT OF ACCOUNTING INFORMATION. Gadjah Mada International Journal of Business, 6(1).

Hasan, A., \& Javed, M. T. (2009). Macroeconomic influences and equity market returns: A study of an emerging equity market. Journal of Economics and Economic Education Research, 10(2), 47.

Hashemzadeh, N., \& Taylor, P. (1988). Stock prices, money supply, and interest rates: the question of causality. Applied Economics, 20(12), 1603-1611. https://doi.org/https://doi.org/10.1080/00036848800000091

Hernendiastoro, A. (2005). Pengaruh kinerja perusahaan dan kondisi ekonomi terhadap return saham dengan metode intervalling. (unpublished doctoral dissertation). Universitas Diponegoro, Indonesia.

Hovakimian, A. (2004). The Role of Target Leverage in Security Issues and Repurchases. The Journal of Business, 77(4), 1041-1072. https://doi.org/10.1086/422442

Hovakimian, A., Hovakimian, G., \& Tehranian, H. (2004). Determinants of target capital structure: The case of dual debt and equity issues. Journal of Financial Economics, 71(3), 517-540. https://doi.org/10.1016/S0304-405X(03)00181-8 
Hovakimian, A., Opler, T., Titman, S., The, S., Analysis, Q., Mar, N., ... Titman, S. (2001). The Debt-Equity Choice Published by: Cambridge University Press on behalf of the University of Washington School of Business Administration Stable URL : http://www.jstor.org/stable/2676195 The Debt-Equity Choice, 36(1), 1-24.

Hsu, Y.-H., \& Fang, W. (2009). Intellectual capital and new product development performance: The mediating role of organizational learning capability. Technological Forecasting and Social Change, 76(5), 664-677. https://doi.org/https://doi.org/10.1016/j.techfore.2008.03.012

Ibrahim, M. H., \& Aziz, H. (2003). Macroeconomic variables and the Malaysian equity market. Journal of Economic Studies, 30(1), 6-27. https://doi.org/10.1108/01443580310455241

Idris, I., \& Bala, H. (2015). Firms' Specific Characteristics and Stock Market Returns ( Evidence from Listed Food and beverages Firms in Nigeria ), 6(16), 188-201.

Kamukama, N., Ahiauzu, A., \& Ntayi, J. M. (2011). Competitive advantage: mediator of intellectual capital and $\begin{array}{lllll}\text { performance. Journal of } & \text { Intellectual } & \text { Capital, } & 12(1), & 164 .\end{array}$ https://doi.org/https://doi.org/10.1108/14691931111097953

Kheradyar, S., Ibrahim, I., \& Nor, F. M. (2011). Stock return predictability with financial ratios. International Journal of Trade, Economics and Finance, 2(5), 391. https://doi.org/https://doi.org/10.7763/ijtef.2011.v2.137

Korajczyk, R. A., \& Levy, A. (2003). Capital structure choice: Macroeconomic conditions and financial constraints. Journal of Financial Economics, 68(1), 75-109. https://doi.org/10.1016/S0304-405X(02)00249-0

Kothari, S. P., Lewellen, J., \& Warner, J. B. (2006). Stock returns, aggregate earnings surprises, and behavioral finance. Journal of Financial Economics, 79(3), 537-568. https://doi.org/10.1016/j.jfineco.2004.06.016

Kouser, R., Awan, A., Gul-e-Rana, \& Shahzad, F. A. (2011). Firm size, leverage and profitability: Overriding impact of accounting information system. Business and Management Review, 1(10), 58-64. Retrieved from http://www.businessjournalz.org/bmr

Kwon, C. S., \& Shin, T. S. (1999). Cointegration and causality between macroeconomic variables and stock market returns. Global Finance Journal, 10(1), 71-81. https://doi.org/10.1016/S1044-0283(99)00006-X

Lim, L. K. (2009). Convergence and interdependence between ASEAN-5 stock markets. Mathematics and Computers in Simulation, 79(9), 2957-2966. https://doi.org/https://doi.org/10.1016/j.matcom.2008.12.004

Maysami, R. C., \& Koh, T. S. (2000). A vector error correction model of the Singapore stock market. International Review of Economics and Finance, 9(1), 79-96. https://doi.org/10.1016/S1059-0560(99)00042-8

Mukherjee, T. K., \& Naka, A. (1995). Dynamic relations between macroeconomic variables and the Japanese stock market: an application of a vector error correction model. Journal of Financial Research, 18(2), $223-237$. https://doi.org/https://doi.org/10.1111/j.1475-6803.1995.tb00563.x

Omran, M. M. (2003). Time Series Analysis of the Impact of Real Interest Rates on Stock Market Activity and Liquidity in Egypt: Co-integration and Error Correction Model Approach. SSRN Electronic Journal, 8(3). https://doi.org/10.2139/ssrn.420248

Peterson, P. P., \& Fabozzi, F. J. (1999). Analysis of financial statements (Vol. 54). John Wiley \& Sons.

Rahman, A. A., Sidek, N. Z. M., \& Tafri, F. H. (2009). Macroeconomic determinants of Malaysian stock market. African Journal of Business Management, 3(3), 95-106.

Rajan, R. G., \& Zingales, L. (1995). What do we know about capital structure? Some evidence from international data. The Journal of Finance, 50(5), 1421-1460. https://doi.org/https://doi.org/10.3386/w4875

Rogalski, R. J., \& Vinso, J. D. (1977). STOCK RETURNS, MONEY SUPPLY AND THE DIRECTION OF CAUSALITY. The Journal of Finance, 32(4), 1017-1030. https://doi.org/10.1111/j.1540-6261.1977.tb03306.x

Ross, S. A., Westerfield, R., Jaffe, J. F., \& Roberts, G. S. (2002). Corporate finance (Vol. 7). McGraw-Hill/Irwin New York.

Rozeff, S., Rozeff, M. S., \& Kinney, W. R. (1976). Capital market eeasonality: returns. Journal of Financial Economics, 3(4), 379-402. https://doi.org/10.1016/0304-405X(76)90028-3

Saleem, Q., \& Rehman, R. U. (2011). Impacts of liquidity ratios on profitability (Case of oil and gas companies of Pakistan). Interdisciplinary Journal of Research in Business, 1(July), 95-98.

Sari, L. A., \& Hutagaol, Y. R. I. (2009). Debt to equity ratio, degree of operating leverage stock beta and stock returns of food and beverages companies on the Indonesian stock exchange. Journal of Applied Finance and Accounting, 2(1), 1-12.

Shadkam Aga, B., Mogaddam, V. F., \& Samadiyan, B. (2013). Relationship between liquidity and stock returns in companies in Tehran Stock Exchange. Applied Mathematics in Engineering, Management and Technology, 1(4), 278-285. Retrieved from www.amiemt-journal.com

Sieng, C. C., \& Leng, G. K. (2005). Linkages of economic activity, stock price and monetary policy: the case of Malaysia. The Asia Pacific Journal of Economics and Business, 9(1), 48-61. 
Singh, T., Mehta, S., \& Varsha, M. S. (2011). Macroeconomic factors and stock returns: Evidence from Taiwan. Journal of Economics and International Finance, 2(4), 217-227.

Stefano, K. (2015). The Impact of Financial Ratio toward Stock Return of Property Industry in Indonesia. iBuss Management, 3(2), 222-231.

Subramanyam, K. R., \& Wild, J. J. (2009). Financial statement analysis. McGraw-Hill.

Sullivan, A. (2003). Economics: Principles in action.

Titman, S., \& Wessels, R. (1988). The Determinants of Capital Structure Choice. The Journal of Finance, 43(1), 1-19. https://doi.org/10.1111/j.1540-6261.1988.tb02585.x

Tracy, J. A., \& Tracy, T. (2004). How to Manage Profit and Cash Flow: Mining the Numbers for Gold. John Wiley \& Sons.

Ulupui, I. G. K. A. (2007). Analisis Pengaruh Rasio Likuiditas, Leverage, Aktivitas, Dan Profitabilitas Terhadap Return Saham (Studi Pada Perusahaan Makanan Dan Minuman Dengan Kategori Industri Barang Konsumsi Di Bej). Jurnal Ilmiah Akuntansi Dan Bisnis, 1-20. https://doi.org/10.1017/CBO9781107415324.004

Urbanovský, T. (2016). Interconnection of Interest Rate, Price Level, Money Supply and Real GDP: The Case of the Czech Republic. Procedia - Social and Behavioral Sciences, 220, 531-540. https://doi.org/10.1016/j.sbspro.2016.05.529

Vejzagic, M., \& Zarafat, H. (2013). Relationship Between Macroeconomic Variables and Stock Market Index: Co-Integration Evidence From Ftse Bursa Malaysia Hijrah Shariah Index. Asian Journal of Management Sciences and Education, 2(4), 94-108.

Ye, S., Chen, H., \& Jin, X. (2006). Exploring the moderating effects of commitment and perceived value of knowledge in explaining knowledge contribution in virtual communities. PACIS 2006 Proceedings, 25.

\section{Copyrights}

Copyright for this article is retained by the author(s), with first publication rights granted to the journal.

This is an open-access article distributed under the terms and conditions of the Creative Commons Attribution license (http://creativecommons.org/licenses/by/4.0/). 